\title{
THE FINANCIAL SUPPORT AND THE ADMINISTRATIVE NEEDS OF TERRORIST OPERATIONS
}

\author{
Camelia Popa ${ }^{1}$ \\ Liviu Uzlău \\ Corina-Maria Ene $e^{3}$
}

\begin{abstract}
Financing terrorism refers to a specific activity with many particular features. The financial resources it drowns are represented by both voluntary sympathizers' contributions and illegal revenues, generated by important criminal activities. Within the terrorist organization though, financial contributions of Diaspora and donations made by political and religious ideology sympathizers hold the most important role. Terrorists use similar techniques as money laundering to avoid the authorities' unwanted attention from and to protect the identities of those who lead the terrorist activities and also the people who benefit from the organization's funding.
\end{abstract}

Key word: terrorism financing, criminal activities, money laundering, organized crime

JEL Codes: K14, K42

\section{Introduction}

The UN Convention for Suppressing Terrorism Financing states that the first objective of a terrorist act is ,to intimidate the population or to force a state authority or an international organization to take or not to take a certain action." 4 A terrorist act implies the deliberate use of violence against civilian targets, intended to create terror amongst the population, governments or international organizations, generally these actions having a political motivation.

In Romania, terrorism is defined by the $535 / 2004^{5}$ law as being the „ensemble of actions and/or threats which pose a public danger and affect national security, having a series of particular features." ${ }^{6}$ According to the $3^{\text {rd }}$ article of the mentioned law, terrorist actions have a transnational nature if the terrorist entity involved carries on actions/activities on the national territory of at least two states or generates important effects in another state than the state of origin.

The acts and facts of terrorist organizations are considered crimes and are punished accordingly if they refer to any of the following factors:

a) They are committed with violence; induce fear, panic, insecurity or terror within the population and governments;

b) They have severe effects on the human or material integrity of individuals or society, as a whole;

\footnotetext{
1 National Bank of Romania, Academy of Economic Studies from Bucharest, Romania, e-mail: carmelita4ever@yahoo.com

${ }^{2}$ National Institute of Economic Research from Romania Academy, Romania,e-mail: liviu_uzlau@yahoo.com

${ }^{3}$ Hyperion University from Bucharest, Romania, e-mail: corina.maria.ene@gmail.com

${ }^{4}$ The UN Convention for Suppressing Terrorism Financing, $2^{\text {nd }}$ article.

${ }^{5}$ Law no. 535/2004 regarding the prevention and fight against terrorism, published in Romanian Official Journal no.1161/8 December 2004.

${ }^{6}$ Are willfully committed by terrorist entities, motivated by extremist conceptions and attitudes, hostile towards other entities, against whom they act by violent and/or destructive means; their goal is to achieve particular objectives of a political nature; they aim human and or material factors within the public authorities and institutions, civilian population or any other segment belonging to these two; they induce a powerful psychological effect on the population, destined to raise the attention on the pursued goals.
} 
c) They pursue the achieving of political goals, by forcing the authorities of the state/international authority to adopt decisions in favour of the terrorist organization.

Generally the main goal of terrorism is to intimidate the population/governments or to force a certain government/organization to take or not to take a certain action, the motivation for such an approach being either ethnical or religious, seldom being identified as a certain individual's personal resolution. Consequently, it's not the profit that guides terrorist actions, this being the motivation of other organizations from the area of organized crime.

Organized crime groups and terrorist networks do have some behavioural similarities:

- both act as rational factors;

- both use extreme violence and threat with retaliation;

- both are involved in kidnapping, murder and extortion;

- both take secret actions, rendering them public only in supporting or friendly countries or territories;

- $\quad$ both break the law and disrespect the notion of rule of law (except for sponsor states);

The economic theory referring to terrorism starts from the premise that terrorists are rational actors. Basically, they search for a redistribution of power and financial resources that cannot be touched by the rightful law. Terrorism aims for the destabilization of economy and politics from a certain country but also for the publicity of some political and religious ideologies. On the long term, terrorists intend to impose their own beliefs. As long as the marginal profit of terrorist activities surpasses the marginal costs, terrorism will be the chosen path for achieving certain objectives.

On one hand, individual behaviour, group dynamics and terrorist environment contribute to explaining the phenomenon itself, because all of these are inextricably tied to the estimated costs of terrorism. On the other hand, terrorists and their supporters are influenced by specific national factors, which can encourage or, on the contrary, discourage acts of terror, reflecting the cost to benefit rapport of the terrorist environment.

For example, during periods of economic recession the costs for manifesting violence can be reduced, which leads to the worrying escalation of aggressive behaviour, while in periods of economic prosperity, the relative costs of violence increase, making it manifest in a lesser rate.

\section{Terrorism costs and financial resources}

Terrorism generates immense costs. First of all, we are discussing direct costs, materialized in the human victims and damage. Secondly, we have a series of indirect costs, linked to the economic and political realities of the day. These correspond to the immediate goals of terrorism, political and economic destabilization. Thus, most authors state that the terrorist phenomenon has an influence in interstate commerce, capital flows, tourism and the development of some industrial branches. For example, in Israel, because of the constant terrorist threat, financial resources are directed primarily towards the military industry, impoverishing the non-military branches of the national economy.

Terrorism also involves political costs. These kinds of attack amplify the risk of government overthrow and can also influence the forming of political coalitions or the elective behaviour of the population (or at least a certain segment). Also, there is the risk that the governments of the states affected or targeted by terrorism would impose a series of measures, legislative or otherwise, which, sooner or later, would have an effect on human rights or freedom of the citizens.

The financing of terrorism is regarded by the WB and IMF as being ,the financial support, by any methods, of terrorism or those who support, plan or are involved in acts of terrorism"7.

\footnotetext{
${ }^{7}$ Schott Paul Allan (2006), Reference Guide to Anti-Money Laundering and Combating the Financing of Terrorism, 2nd edn, World Bank / IMF, Washington D.C.
} 
In a purely technical approach, the methods used by terrorist groups for obtaining financial results are different in certain aspects from those used by organized crime (Figure no. 1).

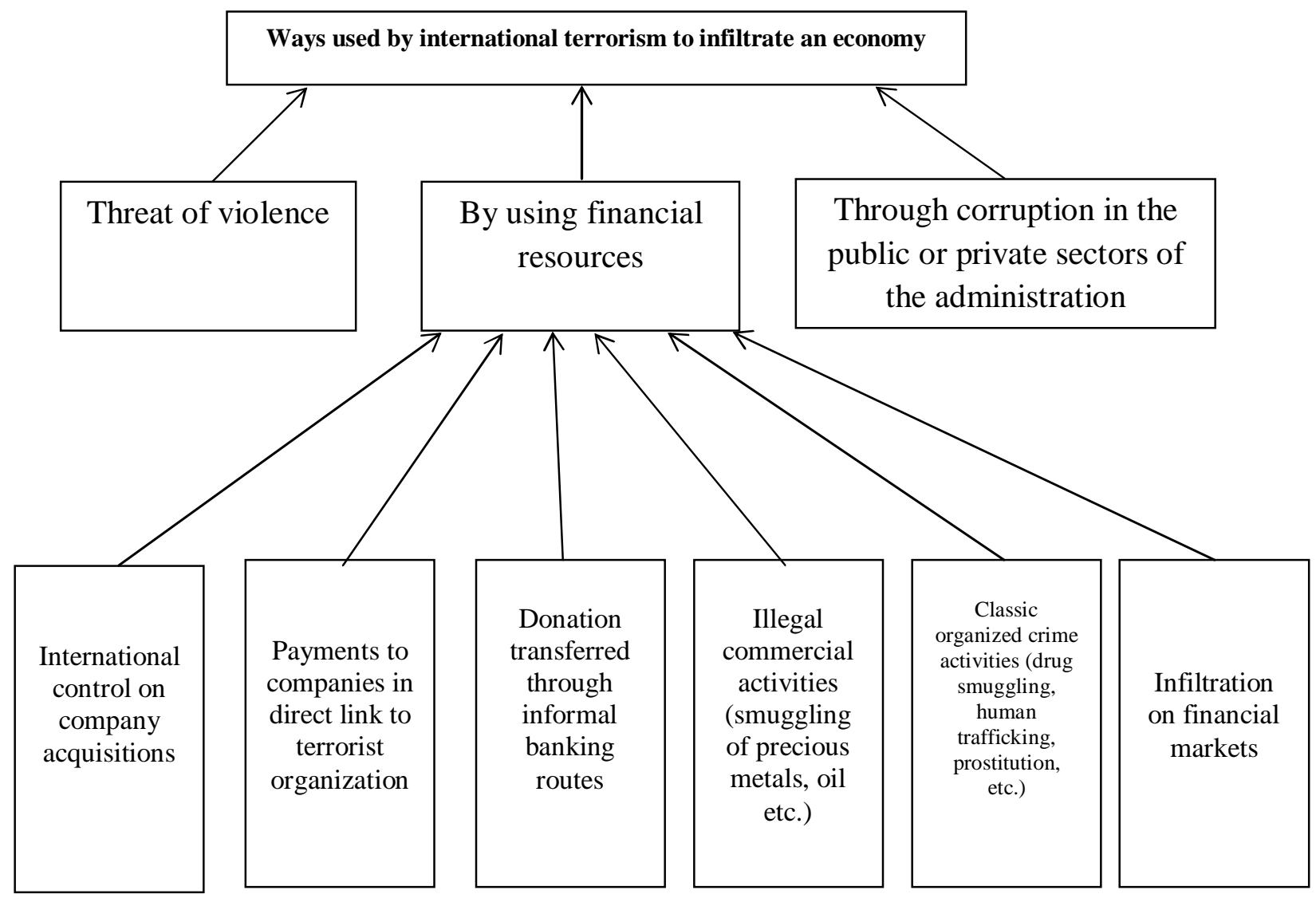

Figure no.1. - How international terrorism infiltrate an economy

Source: own adaptation of Schneider Friedrich (2011), The Financial Flows of the Transnational Crime: Some

Preliminary Empirical Results, EUSECON, Economics of Security Working Paper 53, Berlin, page 10

Terrorism is supported by occult funding (,dirty money”) or by laundered money derived from crime, alongside other funds used for preparing and committing criminal acts.

Legal activities are also a strong financial support for terrorist organizations (donation, sales, and acts of commerce). Therefore it's becoming hard to identify which resources are derived from criminal activity amongst the funds derived from ordinary legal activity which support terrorist organizations, when these funds are mixed.

Thence, not all funding used by terrorists come from illegal activities. There are states which provide support to terrorist groups (ex. Afghanistan, Pakistan). They have a sufficiently developed infrastructure, capable of collecting and distributing funds towards terrorist organizations. Substantiation is the fact that most of Bin Laden's companies were found in such regions.

A person, who owns enough financial resources, could deliberately provide substantial funds to the terrorist organizations. As an example, it is said that Bin Laden has contributed with significant amount of funds from his assets to set up the terrorist network known as Al-Qaeda.

Al-Qaeda is a terrorist network with strong international connections, mainly targeted towards the conflict theatres (within different states), where it had the possibility to easily and rapidly manage the available funds. All its operations have been guided by a particular cause, namely the religion. This group represented one more inspirational source for other contemporary terrorist organizations. Their typical operational characteristics are: 
- Low costs/basic technologies - they allow putting on some major impact attacks against lives and integrity of persons, states and economies;

- Flexible structure, decentralization, independent decisions and actions;

- Important resources and financial means, designated to plan and future carry out terrorist attacks;

- Limited need to conceal/dissimulate goods or other different financial figures;

- Self-financing, based on illegal activities (fraud, extortion, etc.), but also on legal ones (donations through charities). The terrorists use various financial resources, depending on their actions motivation, modus operandi and resistance against legal rules. Often, though, legal funds become "dirty", by using them with the purpose of committing crimes connected to preparation/execution of attacks.

It is well-known that $9 / 11$ attacks have been made possible by the lack of an adequate financial control, which allowed Al-Qaeda to provide and receive funds under the protection of the anonymity, and thus to ensure financial resources to bring their plans into life.

Terrorist organizations' volunteer financial contributors generally are sympathetic with their ideologies (ethnic or/and religious) and make donations through some charitable organizations involved in the terrorism financing.

Moreover, if the terrorist organization is acting in the name of religion, the financing means take an illusory Samaritan connotation. According to the religious doctrine, within a community, the wealthy people should help and support the poor ones. Usually, these types of funds are collected in a mosque (offertory box) or in Islamic cultural centers.

Donations to NGOs and various charitable organizations have legal status in most countries of the world. Problems occur when the objectives of such NGOs are not legal, or when charitable funds collected are in reality just a "smokescreen" for the profits generated by illegal activities.

True transnational financial engine of al-Qaeda and its supporters was yet represented by legal businesses (companies, agricultural and forestry exploitation, etc.). The assets portfolio of the terrorist group includes real estate located in London, Paris and the French Riviera, but also financial ramifications in different industries (food industry in Denmark, wood and paper industry in Norway, medical industry in Sweden).

With the purpose to hide the origin of funds, the terrorist organizations, in order not to unmask, must use values with apparently legal origin. Funds are provided to the terrorist organizations only after they have been "transformed" in legal values. But there is also the possibility of committing terrorist acts for the purpose of values acquisition, that subsequently to laundering to be used to finance other terrorist activities.

It is almost impossible to control the origin and destination of funds used by terrorist organizations by the method of investigating international transfers volume because international transfers made to finance the terrorism is not characterized by a large amount, but rather through a repetitive and discreet character.

Also, it is almost impossible to determine the evolution of these phenomena - money laundering and the financing of terrorism - because the activities it involves can neither be observed nor recorded. As a result, the governmental bodies' concerned efforts in this direction are considerable.

The first step in identifying and capturing financial flows designated to finance the terrorism is guided by the necessity to understand the modern needs of financing the terrorist groups. The costs associated with the planning and execution of terrorist attacks, but also those generated by maintaining hierarchical structures, the development of the Organization and promoting ideologies are considerable.

Therefore, the funds used for supporting terrorism can come from legal sources, criminal activities or of both (Figure no. 2). Of great importance is to disguise the terrorism funding source, 
whether the source is legal or illegal. If the source can be hidden, it can be considered to remain available for future funding of terrorist activities.

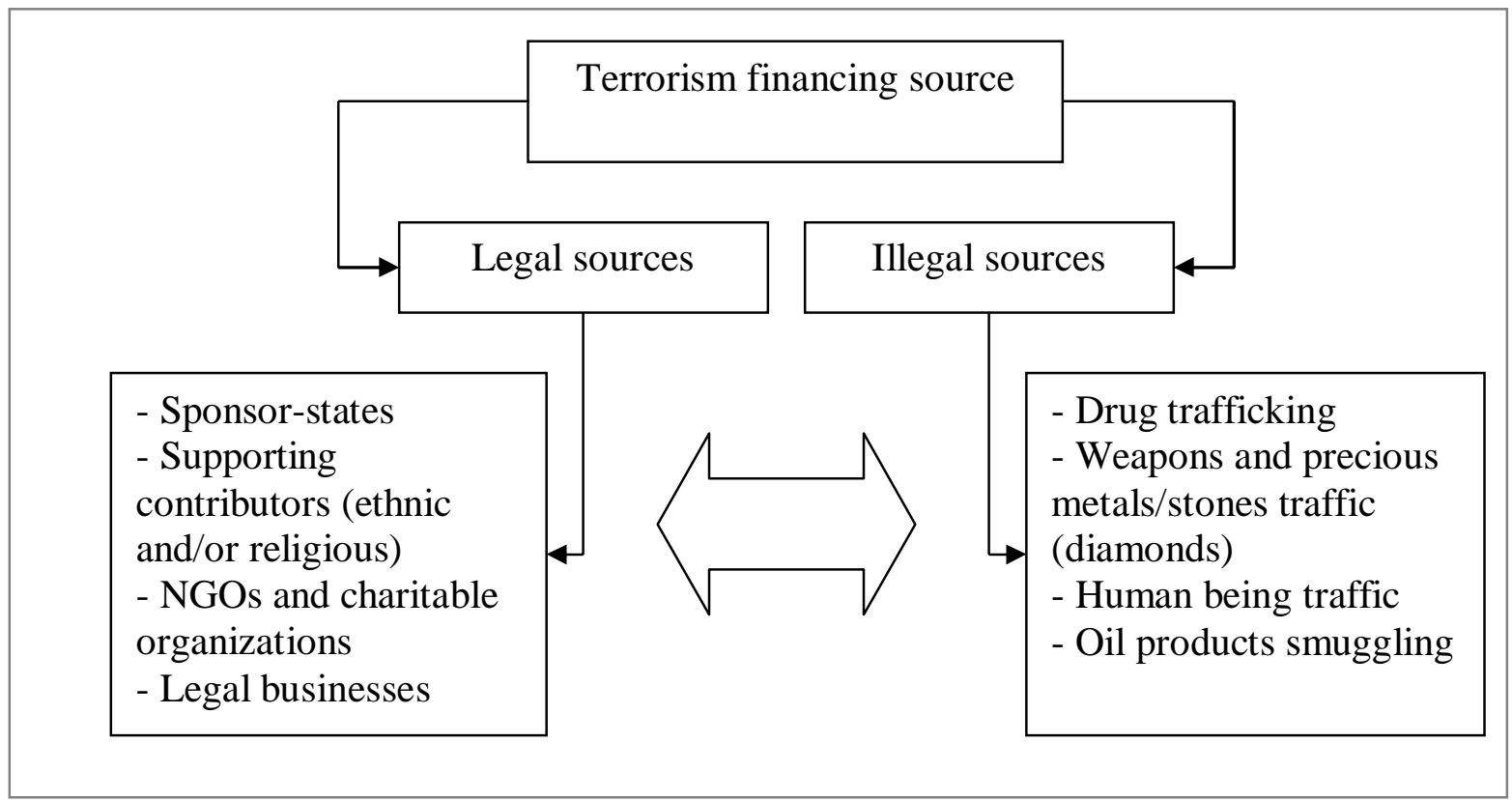

Figure no. 2. - Terrorism financing sources

Source: own vision

\section{Terrorism financing - logistic and operational support}

All terrorist groups need logistical support. There are costs involved by maintaining a network, supporting cells and procurement of material goods (tools, weapons, communication systems, false identification documents, etc.). These activities, together with recruitment, training and transport involve significant financial resources.

In recent years, a growing number of important FATF member States reported new terrorist financing situations and methods, which indicate that perhaps more terrorist networks are trying to expand their funding base.

Type of resources designated for the financing of both operational activities, and the support ones, varies depending on the type of terrorist organization, the traditional values adopted, hierarchical clustering, the level of decentralization, but also on the mutual support offered by similar organizations.

Financing needs of terrorist groups are played on two interdependent strands:

1. Direct costs associated with terrorist attacks (financing specific terrorist operations);

2. Additional organizational costs, maintenance and development of the organizational infrastructure, necessary to ensure the promotion of the ideology of a terrorist organization.

Applications for funding of terrorist groups on ensuring direct operational support include:

- Direct costs of terrorist attacks. The necessary material means to set up attacks include vehicles, weapons, explosives and improvised bombs, maps, surveillance equipment, etc. These costs are generally low compared with the damage that they create.

- Salaries, means of subsistence and communications. Operative agents should be provided with daily livelihood means and sometimes to satisfy certain addictions. Also, a terrorist cell must communicate with the members of its network and possibly with the parent network. The financial obligations arising from the necessity to cover these needs raise to quite large sums.

- Training, travel and logistics. Exercises for continuous physical training, but also for ideological indoctrination represent as well a very important investment for terrorists. Also 
easing travel for documentation regarding the target objectives assumes a range of costs related to the purchase of false travel documents, accommodation etc., considered to be relatively high.

- Joint funding. When a cell is part of a terrorist network and shares religious and ideological objectives with other cells or networks, they can provide financial support to each other. Additional organizational requests refer to:

- Charitable organizations: are sometimes complicit in supporting the objectives of terrorist groups;

- Outlets and media: in addition to the function of providing social and citizen's welfare to the paramilitary organizations, terrorist groups are heavily supported by a sophisticated system of public relations and media, which promotes the ideology of terrorism. In the virtual environment terrorist organizations have websites dedicated to recruitments, but also to the transmission of messages to claim some bloody attacks. Through specific media tools they make propaganda of violence, suicide, etc., attitudes that bring serious damage to international stability.

Taking into account the seriousness of the criminal phenomena presented, the connections and trends which manifests, Government bodies and authorities with clear responsibilities in countering organized crime should cooperate with similar bodies, specialized in antiterrorism, because any criminal network identified should be evaluated also from the perspective of whether it is a cell of a terrorist group ${ }^{8}$.

\section{Conclusions}

Terrorist financing mechanisms have evolved explosively after 2001 by infiltrating into the global formal and informal financial system, which terrorists can easily manipulate ${ }^{9}$.

Bodies involved in actions for the identification and tracking of terrorist funds have released a list of institutional constraints which must be defeated in the fight against the financing of terrorism $^{10}$ :

- It takes a full and complex analysis of the financial transactions, which obliges institutions' involved staff to work with accountants, bankers and financial experts;

- It is necessary to analyze reports on suspicious activities and the transmission of relevant information between FIUs from different countries/regions;

- It is necessary to disseminate information locally as well, because terrorist organizations involve also the organized crime specific actions;

- The process of gathering the relevant data and information on the financing of terrorism requires governmental cooperation at the institutional level to ensure financial national and international integrity.

In this context, financial information services', but also the secret services' actions, put at the service of the fight against the financing of terrorism, should combine efforts and expertise of specialists from different fields. It is necessary to detect trends and indicators in relation to this phenomenon. The identification and collation of such information is a challenge to international cooperation mechanisms. Only in this way it can be created a zoom of funding terrorism and the terrorist groups' own financial resources movement puzzle.

\footnotetext{
${ }^{8}$ Hedeşiu Emil (2005), Countering cross border organized crime, National Defense University Publishing House, Bucharest, pg. 196.

${ }^{9}$ Giraldo J.K., H.A. Trinkunas (2007), Terrorism financing and state responses: a comparative perspective, Stanford, Calif., Stanford University Press: 1-20, 282-296, pg. 11.

${ }^{10}$ Schneider Friedrich (2010), The (Hidden) Financial Flows of Terrorist Organizations: A literature Review and Some Preliminary Empirical Results, IZA Discussion Paper No 4860, pg. 7 - 8.
} 


\section{References}

1. Giraldo J.K., Trinkunas H.A., 2007. Terrorism financing and state responses: a comparative perspective, Stanford, Calif., Stanford University Press, pp.1-20, 282-296

2. Hedeşiu E., 2005. Countering cross border organized crime, National Defense University Publishing House, Bucharest

3. Schneider Fr., 2010. The (Hidden) Financial Flows of Terrorist Organizations: A literature Review and Some Preliminary Empirical Results, IZA Discussion Paper, No 4860

4. Schneider Fr., 2011. The Financial Flows of the Transnational Crime: Some Preliminary Empirical Results, EUSECON, Economics of Security Working Paper 53, Berlin

5. Schott P. A., 2006. Reference Guide to Anti-Money Laundering and Combating the Financing of Terrorism, 2nd ed., World Bank/IMF, Washington D.C.

6. *** UN Convention for countering Terrorism Financing

7. *** Law no. 535/2004 on preventing and countering terrorism, published in Romanian Official Journal no. 1161/8 December 2004. 